\title{
2009 年度精密工学会論文賞・沼田記念論文賞・高城賞・研究奨励賞業績の紹介
}

\section{9 年度（第 6 回）精密工学会論文賞}

ICP とリージョングローイングを組み合わせた

機械部品計測メッシュのユークリッド対称性認識手法

精密工学会誌 75 巻 4 号（75-4), pp. 554-560

本論文は，産業用 CT で得られた計測データを CAD などに応用する際，モデル構築やメッシュデータ量の圧縮に役立 つユークリッド対称性認識アルゴリズムに関するもので, 実際に得られた機械部品計測デー夕に対して高精度で対称性を 認識できることを検証をしている。論文の工業的有用性と工学的意義は高く評価でき, 精密工学の発展に寄与するところ が大きいと認められ，論文賞受賞に值するものと判断される.

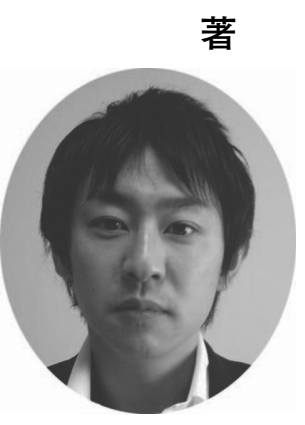

溝口 知 広

平成 21 年北海道大学 大学院情報科学研究科 博士課程修了. 現在, 日本大学工学部情報工 学科助教. 博士（情報 科学)

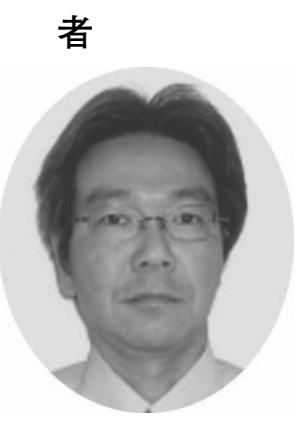

金井理

昭和 62 年北海道大学 大学院工学研究科博士 課程修了。東京工業大 学助教授を経て, 現 在, 北海道大学大学院 情報科学研究科教授. 工学博士 


\section{マイクロ切削工具切れ刃形状の三次元測定装置に関する研究 一測定装置の構築と切れ刃形状測定実験一 \\ 精密工学会誌 75 巻 7 号 (75-7), pp. 892-896}

本論文は, 微小高精度部品作成に関してはなくてはならない技術の一つであり, 超精密加工用マイクロ工具切れ刃の三 次元形状を高精度かつ迅速に測定できるシステムを構築した技術は, 新規性, 独創性に富むと同時に工学的・工業的有用 性が高く, 精密工学の発展に寄与するものと認められる.

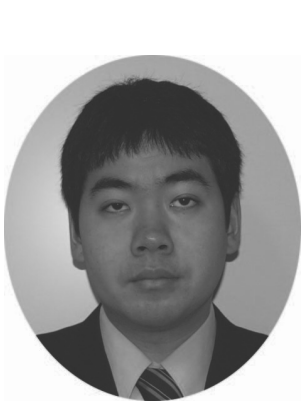

浅 井 岳 見

平成 20 年東北大学大 学院工学研究科ナノメ カニクス専攻博士課程 前期修了. 東北大学大 学院工学研究科ナノメ カニクス専攻博士課程 後期 3 年の課程在学 中. 修士 (工学)

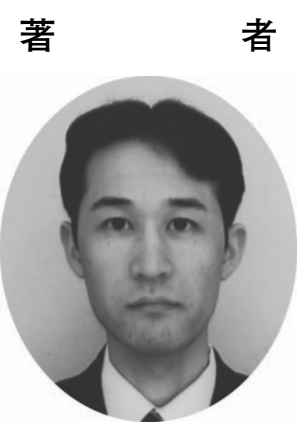

荒井義和

平成 17 年東北大学大 学院工学研究科機械電 子工学専攻博士課程後 期 3 年の課程修了. 東 北大学大学院工学研究 科ナノメカニクス専攻 助教. 博士 (工学)

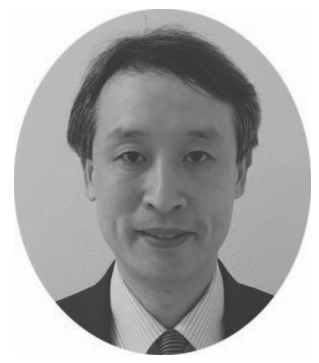

高

偉

平成 6 年東北大学大学 院工学研究科精密工学 専攻博士課程修了。東 北大学大学院工学研究 科ナノメカニクス専攻 教授. 博士 (工学)

Fundamental investigation of subsurface damage in single crystalline silicon caused by diamond machining

Precision Engineering Vol. 33/4, pp. 378-386

本論文は, 透過電顕, 顕微ラマンなど複数の観測手法により単結晶 Si の微小傾斜プランジ切削における材料構造変化と 加工条件との関倸を明らかにし，高圧相変態理論に基づく加工変質層形成モデルを提案し，高信頼性の加工計測を実現し たことは極めて高く評価でき, 工学的㧍よび工業的波及効果がある研究で, 精密工学の発展に寄与するものと認められる.

著

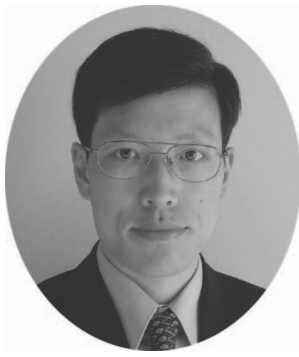

閻

紀 旺

平成 12 年東北大学大 学院工学研究科機械電 子工学専攻博士課程修 了. 現在, 東北大学大 学院工学研究科ナノメ カニクス専攻准教授。 博士 (工学)

者

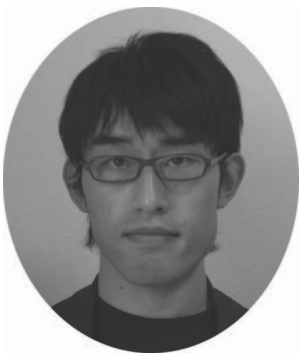

朝 見

平成 19 年東北大学大 学院ナノメカニクス専 攻修士課程修了. 現 在アイシン・エィ. ダブリユ株式会社。修 士 (工学)

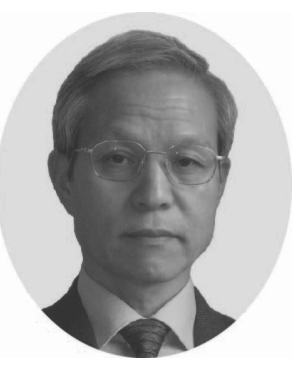

原田博 文

昭和 55 年東北大学大 学院工学研究科博士課 程修了. 現在, シルト ロニック・ジャパン株 式会社生産・技術本 部. 工学博士

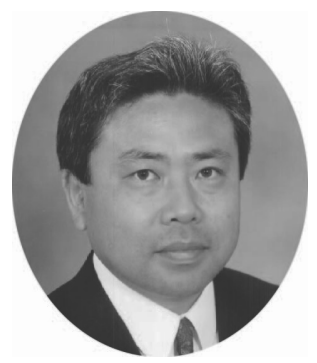

厨 川 常

昭和 62 年東北大学大 学院工学研究科精密工 学専攻博士課程修了. 現在, 東北大学大学院 工学研究科ナノメカニ クス専攻教授。博士 (工学) 


\title{
2009 年度（第 26 回）精密工学会沼田記念論文賞
}

\author{
水酸化フラーレンスラリーを用いた $\mathrm{Cu}-\mathrm{CMP}$ 加工法に関する研究 \\ 一研磨特性の検証一 \\ 精密工学会誌 75 巻 4 号 (75-4), pp. 489-495
}

本論文は水酸化フラーレンと銅との化学的反応を CMP 加工に応用することを提案し，フラーレンの水酸基の数の違い と研磨特性との関倸を実験により詳細に検討したものである。その結果, 適切に水酸基数を選べば RMS 值 $1 \mathrm{~nm}$ 以下の平 坦化特性が得られることを明らかにしており，今後の精密工学の発展に寄与するところ大と認められる.

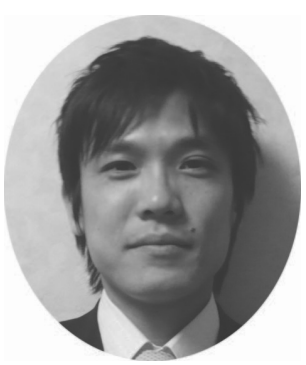

田 近 英 之

平成 21 年大阪大学大 学院工学研究科機械工 学専攻修了. 現在, パ ナソニック株式会社勤 務. 修士（工学）

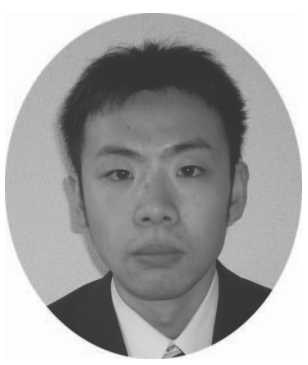

田名田 祐 樹

平成 19 年大阪大学大 学院工学研究科機械シ ステム工学専攻博士前 期課程修了。現在，株 式会社デンソーに勤 務. 修士（工学）

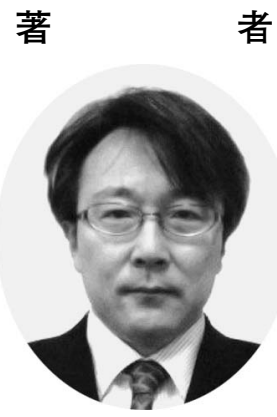

高谷裕浩

平成 4 年北海道大学大 学院工学研究科精密工 学専攻博士課程修了. 大阪大学大学院工学研 究科教授. 博士（工 学)

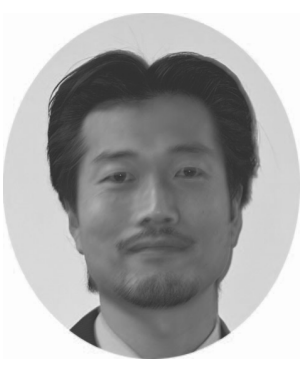

小久保

研

平成 10 年大阪大学大 学院工学研究科分子化 学専攻博士後期課程修 了. 平成 10 年大阪大 学大学院工学研究科応 用化学専攻助手. 平成 19 年大阪大学大学院 工学研究科応用化学専 攻講師 (平成 20 年 平成 21 年米国マ开チ ユーセッツ大学客員准 教授兼任)。現在，大 阪大学大学院工学研究 科応用化学専攻講師。 博士 (工学)

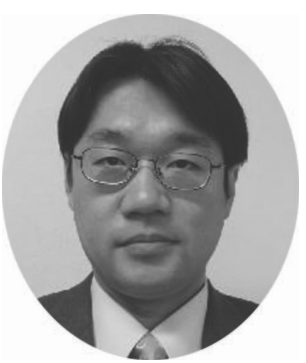

林 照 剛

平成 13 年大阪大学大 学院工学研究科機械 ステム工学専攻博士後 期課程修了. 大阪大学 大学院工学研究科准教 授. 博士 (工学)

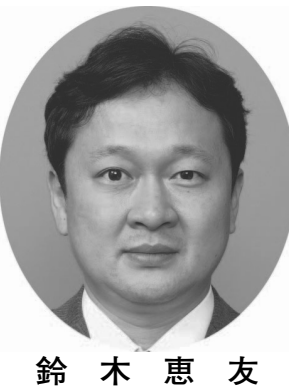

平成 10 年北陸先端科 学技術大学院大学材料 科学研究科物性科学専 攻博士後期課程修了. 現在, 九州工業大学大 学院情報工学研究院機 械情報工学研究系。博 士 (材料科学) 
High-accuracy displacement metrology and control using a dual Fabry-Perot cavity with an optical frequency comb generator

Precision Engineering Vol. 33/2, pp. 187-193

本論文は, 光周波数コムと二つのファブリペロー共振器を組み合わせた変位計測手法に対して, 屈折率変動などの環境 の影響を補償することにより高精度化を行っていることが評価できる．実現した装置では，変位 $14 \mu \mathrm{m}$ に対して分解能 24 $\mathrm{pm}$, 不確かさ $190 \mathrm{pm}$ を達成している。この結果は計測標準の観点から高く評価でき, 工学的・工業的な有用性が高く, 精密工学の発展に寄与するものと認められる。

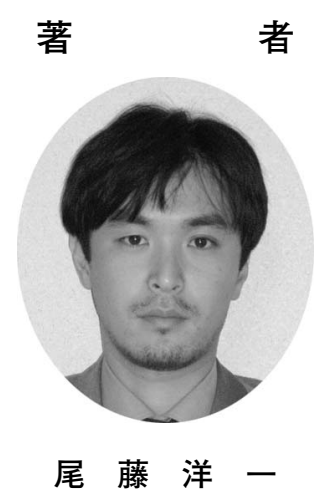

平成 10 年神戸大学大 学院自然科学研究科博 士後期課程知能科学専 攻修了. 現在, 独立行 政法人産業技術総合研 究所計測標準研究部門 長さ標準研究室主任研 究員. 博士 (工学) 


\section{9 年度（第 12 回）精密工学会高城賞}

すべりねじステージの制御構造の一研究

一機械非線形特性の把握と制御一

精密工学会誌 75 巻 8 号（75-8), pp. 1000-1004

本論文は, 半導体露光装置のウエ八駆動に用いられるすべりねじステージのショットずれ現象の要因がグリースの粘性 の非線形性にあることを明らかにし，その対策としてゲインスケジューリング制御を提案し，実機による実験検証を行っ たものである。得られた成果は半導体露光装置の位置決め精度と高速整定性を両立させ半導体製造の生産性向上に貢献し 精密工学会高城賞にふさわしいものと認められた.

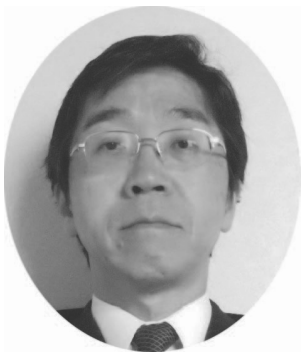

牧 野内進

昭和 53 年早稲田大学 理工学部電気工学科修 了。株式会社ニコン新 事業開発本部技監

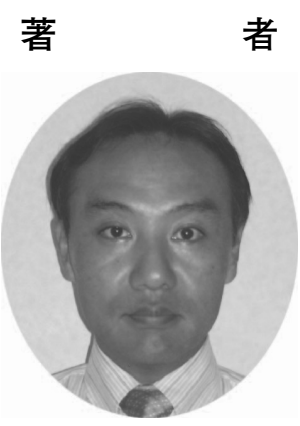

坂 本 英 昭

昭和 60 年東京大学工 学部精密機械工学科修 了。株式会社ニコン精 機カンパニー開発本部 第 1 設計部ゼネラルマ ネージャー

受賞した主たる研究機関

株式会社ニコン

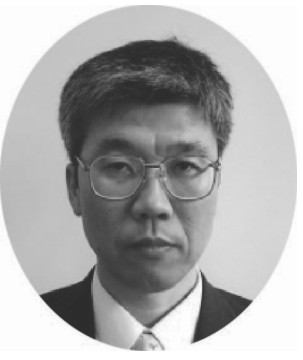

涌 井伸二

昭和 54 年信州大学工 学研究科修士課程修 了. 東京農工大学電気 電子工学科教授. 博士 (工学) 


\section{液滴塗布ヘッド内に打けるレーザ生成気泡の挙動観測}

精密工学会誌 75 巻 12 号 (75-12), pp. 1470-1475

本論文は，産業用インクジェット技術で問題となる微小気泡による吐出異常の高精度検出技術の開発を目的として，サ イズ制御された気泡の発生方法を提案するとともに, 発生した気泡の観察と作用する力の詳細な解析からへッド内での気 泡の挙動を解明している。大型フラットパネルデイスプレイ製造ラインへのインクジェット技術の導入に貢献することが 期待され，工学的・工業的有用性が高く，精密工学会高城賞にふさわしいと判断された.

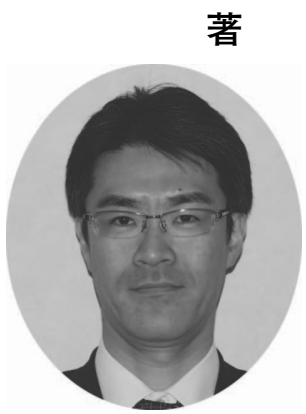

佐 藤

強

平成 20 年東京大学大 学院工学系研究科精密 機械工学専攻博士後期 課程満期退学 株式会 社東芝生産技術セン夕 ーソリューションプロ ジェクト担当主任研究 員 CMC プロジェクト リーダー。修士 (工

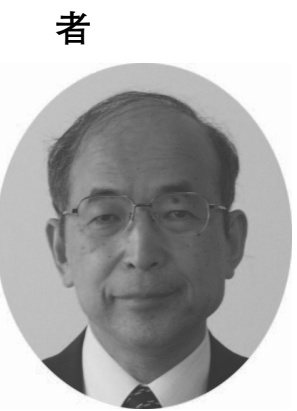

樋 口 俊 郎

昭和 52 年東京大学大 学院工学系研究科精密 機械工学専攻博士課程 修了. 東京大学大学院 工学系研究科精密機械 工学専攻教授. 工学博 士

受賞した主たる研究機関

株式会社東芝 


\section{9 年度（第 6 回）精密工学会研究奖励賞}

離散幾何モデルを基礎として滑らかな曲率変化 を実現した曲面の生成手法

精密工学会誌 75 巻 8 号 (75-8), pp. 1024-1028

小林左千夫，木村文彦

本論文は, 離散曲面から G2 の境界線を生成し, 相互に関連 する二つの主方向曲率変化率が一定となる連続な高級曲面の生 成法を提案した点は, 曲面設計およびリバースエンジニアリン グにおいて高く評価でき, 精密工学の発展に寄与するものと認 められる。

\section{受 賞 者}

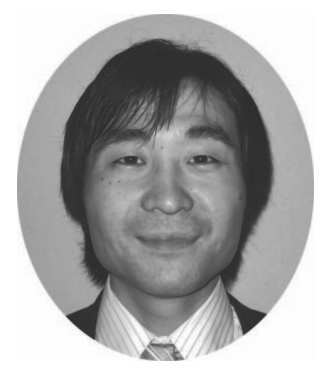

\section{小 林 左千夫}

平成 20 年東京大学大学院 工学系研究科精密機械工学 専攻博士課程修了. 現在, 富士通研究所 IT システム 研究所. 修士 (工学)
Profile measurement of a wide-area resist surface using a multi-ball cantilever system

Precision Engineering Vol. 33/1, pp. 50-55

劉 淑杰, 渡邊健太郎, 陳 欣, 高橋 哲, 高増 潔

従来困難であったフォトリソグラフィに用いられる $\mathrm{Si}$ ウエ 八上のフォトレジストの新しい効率的な表面形状測定法を提案 している. 新開発のマルチポールカンチレバーと白色干渉計に よる原子間力顕微鏡システム, さらに走査ステージの傾きを測 定するオートコリメータを組み合わせた独創的な方法であり， レジスト表面の広領域精密形状測定を実現している。詳細な誤 差解析も行っており, 実証実験により示された実用性も評価で きる。

\section{受 賞 者}

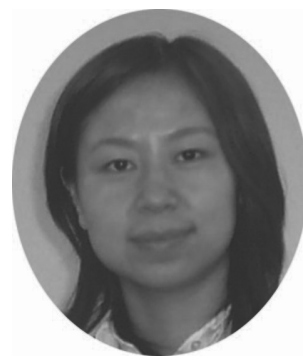

劉淑 杰

平成 19 年東京大学大学院 工学系研究科精密機械工学 専攻博士課程修了. 現在, 東北大学金属材料研究所大 阪センター勤務. 博士（工 学)
Analysis of electromagnetic force in wire-EDM Precision Engineering Vol. 33/3, pp. 255-262 戸村俊輔，国枝正典

本論文は，ワイヤ放電加工におけるワイヤ工具に作用する 4 種類の力, すなわち放電反力, 静電力, 電磁力, 流体力, のう ち電磁力について解析するとともに，鋼では引力が作用する が，銅では作用しないことを解析と実験を絡めて明らかにして いる.このような研究の先には, 放電加工プロセスの完全シミ ユレーションが期待でき, 精密工学会研究奨励賞にふさわしい ものと判断された.

\section{受 賞 者}

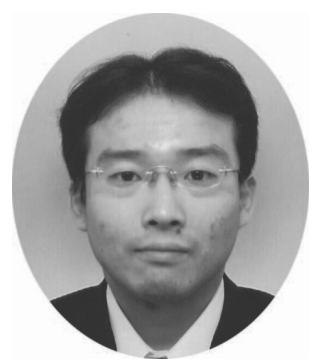

\section{戸 村 俊 輔}

平成 21 年東京農工大学大 学院工学府機械システム工 学専攻博士後期課程修了. 現在，株式会社ソデイック 研究開発本部研究部. 博士 (工学)
Development of a cutting tool with a nano/ micro-textured surface-Improvement of antiadhesive effect by considering the texture patterns

Precision Engineering Vol. 33/4, pp. 425-429

杉原達哉, 榎本俊之

工具すくい面にレーザで $\mu \mathrm{m}$ オーダの溝に $\mathrm{nm}$ オーダの凹凸 を重畳させたパターンを付け, 切削液を捕まえる効果と工具切 りくず接触面を制限する 2 つの効果を付与することにより凝着 損傷を減少させるという業績は高く評価できる。 またこの手法 は, 切削油剤の工具すくい面への進入を解析する上でも利用可 能であり, 精密工学の発展に寄与すると認められ, 精密工学会 研究奨励賞にふさわしいと判断された。

\section{受 賞 者}

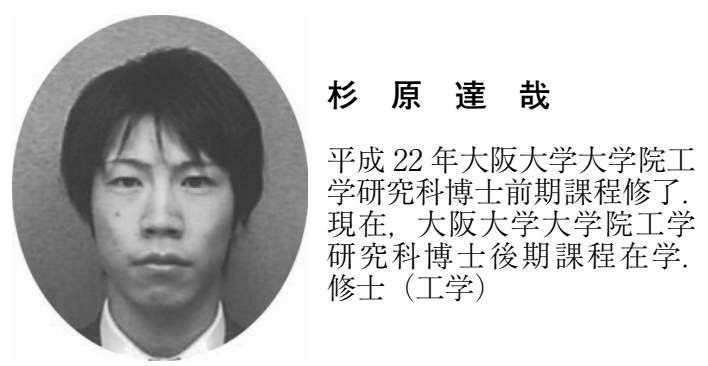

